\title{
Article \\ Applications of Forward Stratigraphic Modelling in Modern Siliciclastic Settings: A Case Study from the Fraser River Delta, Canada
}

\author{
Korhan Ayranci (D)
}

Citation: Ayranci, K. Applications of Forward Stratigraphic Modelling in Modern Siliciclastic Settings: A Case Study from the Fraser River Delta,

Canada. Appl. Sci. 2022, 12, 2399.

https://doi.org/10.3390/

app12052399

Academic Editor:

Paraskevi Nomikou

Received: 8 February 2022

Accepted: 23 February 2022

Published: 25 February 2022

Publisher's Note: MDPI stays neutral with regard to jurisdictional claims in published maps and institutional affiliations.

Copyright: (C) 2022 by the author. Licensee MDPI, Basel, Switzerland. This article is an open access article distributed under the terms and conditions of the Creative Commons Attribution (CC BY) license (https:// creativecommons.org/licenses/by/ $4.0 /)$.
College of Petroleum Engineering \& Geosciences, King Fahd University of Petroleum \& Minerals, Dhahran 31261, Saudi Arabia; ayranci@gmail.com; Tel.: +966-53-140-8025

\begin{abstract}
Forward stratigraphic modelling (FSM) is a relatively new approach that is used to test the importance of parameters that control stratigraphic stacking patterns and to reveal uncertainties such as sedimentation rate and accommodation space. Although FSM is commonly employed in the study of ancient systems, it is rarely applied to modern settings. The Fraser River Delta in Canada provides an opportunity to test applications of FSM in recently deposited sediments in an active sedimentary basin. Because it is un-dammed, the river enables comparison of the modern and ancient systems. It is also a well-studied river system, with sufficient data to generate a realistic model for predicting future scenarios. In this study, Dionisos software is used, and the evolution of the delta over the past 10,000 years is successfully simulated in two steps (5000 years each) using both realistic and real-time data. The main controlling parameters are observed to be the sediment supply and water discharge values, and to a lesser extent, sea level variation. Several possible future scenarios are tested, changing the main parameters to understand and to predict future morphological changes and stacking patterns. Increasing the main parameter values resulted in progradation, while reducing resulted in erosion, particularly in the subaqueous section of the delta. The results of this study can be used to calibrate numerical modelling applications in both modern and ancient deltaic settings.
\end{abstract}

Keywords: forward stratigraphic modeling; Fraser River Delta; Dionisos

\section{Introduction}

Forward stratigraphic modelling (FSM) is a powerful tool to predict reservoir potential in sedimentary basins, including continental, marine, siliciclastic, and carbonate systems. Its applications have been reported to be critical for petroleum exploration, e.g., [1-3] FSM is also an important approach to reveal uncertainties in depositional settings, such as sedimentation rate, water discharge, and sea level fluctuations, which are difficult to determine with conventional research techniques [4,5]. Consequently, FSM is becoming a regular multi-purpose approach to modeling petroleum reservoirs and has been applied commonly in ancient sedimentary basins, particularly in shallow water systems [4-8]. However, it has rarely been applied in modern siliciclastic settings (see exceptions: [9]). Given that this numerical modelling technique has a forward application in stratigraphic architecture, in this study its application is examined in a well-studied modern deltaic system (i.e., the Fraser River Delta, Canada), and its potential applications to predict future stratigraphic architecture (e.g., coastline morphological changes) are tested. These potential applications may help to prevent and better manage natural geo-hazards, such as slope failures, erosion, and subsidence. FSM has the potential to support multiple forms of multidisciplinary research.

The Fraser Delta provides an opportunity to test applications of FSM due to its limited anthropogenic modifications (limited to river dykes in the last several decades) and wellstudied nature. This study tests (1) whether FSM can be applicable to modern studies, (2) what parameters are the main controlling factors (e.g., water discharge, grain size, etc.) 
in reconstructing modern environments, and (3) whether FSM can be utilized to predict future changes in modern deltaic environments.

\section{Study Area}

The Fraser River Delta is situated along the Pacific coast of Canada (Figure 1). It is the largest river in western Canada, and it has been prograding into the Strait of Georgia (SoG), a forearc basin, for about 10,000 years, following the end of the last glaciation [10-12]. This modern delta sits on top of Pleistocene marine- and glacial-origin sand, silt, and, to a lesser extent, gravel deposits [10]. Due to its undammed nature, the Fraser River Delta represents a natural river system, with the exception of some relatively recent modifications along its river (e.g., replacement of dykes).
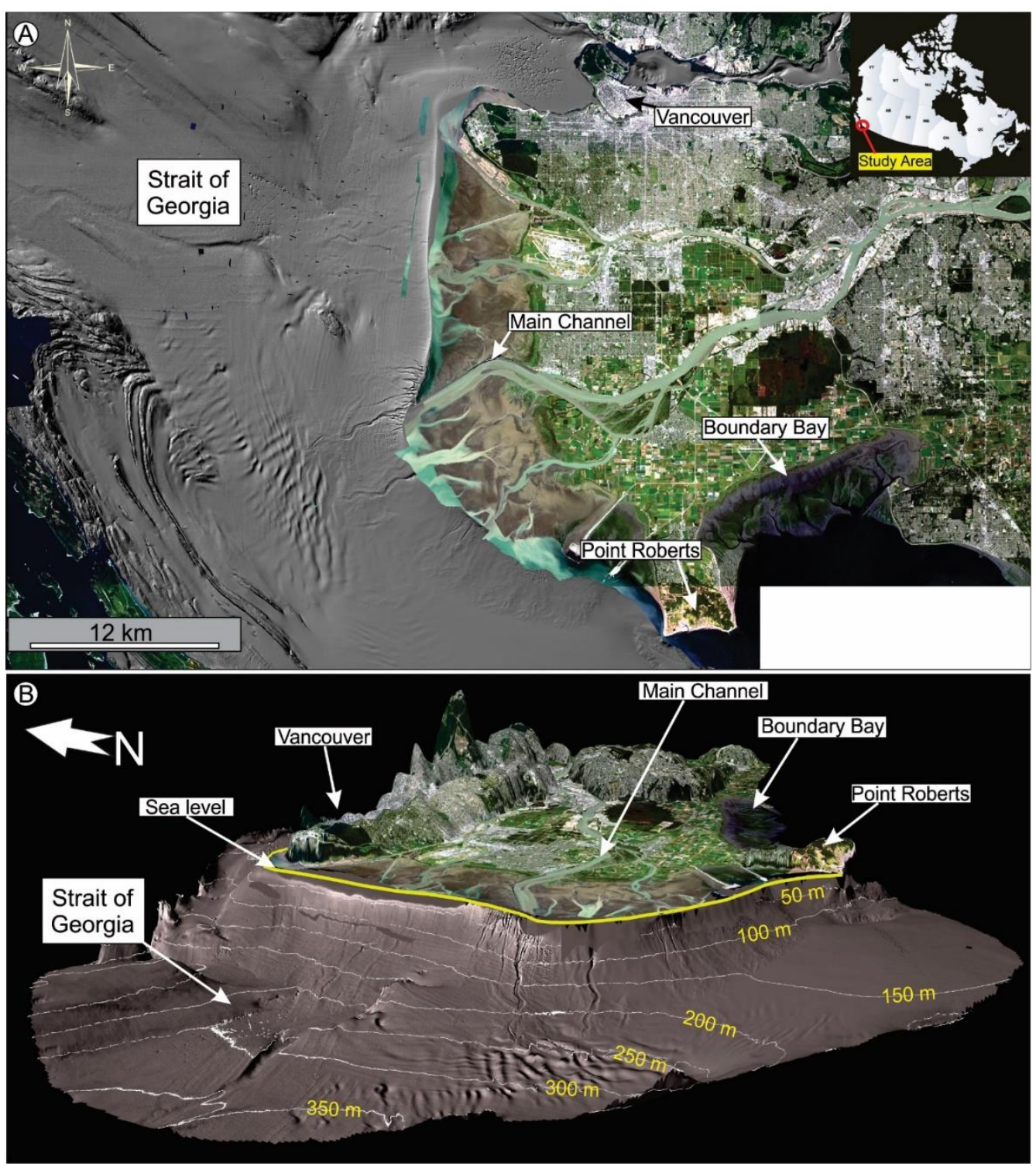

Figure 1. (A) Schematic map of the Fraser River Delta. The gray scale is the multibeam-derived bathymetric map provided by the Geological Survey of Canada, Pacific Division (contour interval: $50 \mathrm{~m}$ ). (B) Three-dimensional block diagram of the Fraser River Delta. The yellow line represents low-tide sea level.

The Fraser River has a dynamic nature, with significant long-term and short-term changes in river discharge, resulting in variations in its progradation rate over time [13]. Between 10,000 BP and $5000 \mathrm{BP}$, the delta prograded approximately $13 \mathrm{~km}$ from the river 
mouth, and another $\sim 9 \mathrm{~km}$ in the last 5000 years, based on terrestrial organic matter distribution, radiocarbon age dating, and marine shell distribution collected from bore hole data [13-15]. The river discharge also dramatically fluctuates. The mean river discharge rate is approximately $3400 \mathrm{~m}^{3} / \mathrm{s}$, while minimum discharge is $1000 \mathrm{~m}^{3} / \mathrm{s}$ and maximum discharge can reach $15,200 \mathrm{~m}^{3} / \mathrm{s}$ during snowmelt-induced freshet [16-18]. Fluctuations in the river discharge also result in variations in transported sediment load. The river annually transports about 17 million tonnes/year of sediment. Under ambient conditions, the river predominantly transports mud-size particles (i.e., silt and clay) into the SoG, while during the freshet, half of this material is sand-sized $[19,20]$.

The SoG is a restricted basin, with complex hydrodynamic processes transporting sediments. These processes include tidal currents, waves, and deep-water renewals [17,21-23]. Waves are the dominant processes in the upper 10-15 $\mathrm{m}$ of the water column [17]. Once the river flow enters into the SoG, suspended sediments are either transported offshore via the river's jet plume (during freshet), or waves transport sediments southward due to the dominant strong wind direction [24], where the sediment settles in the southern parts of the SoG. In the deeper parts of the SoG (>15 $\mathrm{m}$ depth), tidal processes dominate along with deep-water renewals as a subordinate process. Both processes cause net northward sediment transport on and across the delta front and prodelta $[21,23,25,26]$.

\section{Dataset and Methodology}

In order to create a realistic model for the Fraser River Delta and its evolution, the 3D forward stratigraphic modelling software Dionisos@ from IFP (Institut Francais du Petrole) was used. This software can handle complex basinal architectures and considers a large number of input parameters (Table 1), using diffusion laws and long-term basinal scale sediment transport equations $[7,27,28]$. Defining diffusion coefficients can be challenging; thus, testing documented values from similar basins is a common approach, e.g., [29]. The Fraser River represents a forearc region [10]; therefore, both the marine and continental diffusion coefficients (Table 1) used in this study are tested and adopted from other studies in similar basins, e.g., [28]. These coefficient values are reasonable, since a realistic model is achieved using other input parameters that are close to today's real-time values.

\subsection{Input Parameters}

The spatial extent of the model was created based on the distribution of modern sediments, known evolution history of the delta, and other available datasets, e.g., [15,22,30-32]. The simulation covers a rectangular area of $40 \times 60 \mathrm{~km}^{2}$, with a grid size of $0.5 \times 0.5 \mathrm{~km}$ (Table 1). The last 10,000 years is covered in two steps (step 1: 10,000-5000 and step 2: 5000-today) and one additional step (step 3) to test the next 5000 years. In other words, each step was 5000 years.

\subsubsection{Initial Bathymetry}

Generating an initial paleobathymetric map is the most critical step in forward stratigraphic modelling, as it controls the overall accommodation space and the geometry of stratigraphic units. It is also one of the most difficult input parameters to simulate, due to the presence of compaction, tectonic evolution, subsidence, and erosion in basins. It is particularly challenging in ancient systems, although in modern environments, defining paleobathymetry can be easier, as more data are typically available, such as the thickness of modern sediments and geophysical surveys. In addition, the effects of burial by the overlying units can be ignored. In the Fraser River Delta, the thickness of modern deltaic sediments is used, e.g., [33,34], to generate a realistic initial bathymetry. Based on these data, the bathymetry profile resembles an overall fjord-like basin, where the main depo-center is a concave, bowl-shape basin (Figure 2). It should be noted that the model does not extend further south due to limited data availability. In this model, subsidence is neglected, although some minor anthropogenic subsidence has been reported in the delta plain [33]. 
Table 1. Parameters used in modeling.

\begin{tabular}{|c|c|c|c|c|c|}
\hline \multicolumn{3}{|c|}{ Input Parameter } & \multicolumn{3}{|c|}{ Value } \\
\hline \multicolumn{3}{|c|}{ Domain length (x-axis) $(\mathrm{km})$} & \multicolumn{3}{|c|}{60} \\
\hline \multicolumn{3}{|c|}{ Domain length (y-axis) (km) } & \multicolumn{3}{|c|}{40} \\
\hline \multicolumn{3}{|c|}{ Grid size $(\mathrm{km})$} & \multicolumn{3}{|c|}{$0.5 \times 0.5$} \\
\hline \multicolumn{3}{|c|}{ Time steps (yrs) } & \multicolumn{3}{|c|}{5000} \\
\hline \multicolumn{3}{|c|}{ Sediment supply $\left(\mathrm{km}^{3} / \mathrm{Ma}\right)$} & \multicolumn{3}{|c|}{$10,000 \mathrm{~s} 1 ; 9000 \mathrm{~s} 2 ; 9000^{\mathrm{s} 3}$} \\
\hline \multicolumn{3}{|c|}{ River discharge $\left(\mathrm{m}^{3} / \mathrm{s}\right)$} & \multicolumn{3}{|c|}{$6000^{\mathrm{s} 1} ; 4500^{\mathrm{s} 2} ; 4500^{\mathrm{s} 3}$} \\
\hline \multicolumn{3}{|c|}{ Coarse sand $(\%)$} & \multicolumn{3}{|c|}{$5^{\mathrm{s} 1} ; 5^{\mathrm{s} 2} ; 5^{\mathrm{s} 3}$} \\
\hline \multicolumn{3}{|c|}{ Sand $(\%)$} & \multicolumn{3}{|c|}{$20^{\mathrm{s} 1} ; 20^{\mathrm{s} 2} ; 20^{\mathrm{s} 3}$} \\
\hline \multicolumn{3}{|c|}{ Silt $(\%)$} & \multicolumn{3}{|c|}{$45^{\mathrm{s} 1} ; 45^{\mathrm{s} 2} ; 45^{\mathrm{s} 3}$} \\
\hline \multicolumn{3}{|c|}{ Clay (\%) } & \multicolumn{3}{|c|}{$30 \mathrm{~s} 1 ; 30 \mathrm{~s} 2 ; 30 \mathrm{s3}$} \\
\hline \multicolumn{6}{|c|}{ Sediment transport parameters $\left(\mathrm{km}^{2} / \mathrm{ky}\right)$} \\
\hline & & Coarse sand & Sand & Silt & Clay \\
\hline \multirow{2}{*}{ K gravity } & Continental & 20 & 40 & 60 & 80 \\
\hline & Marine & 0.008 & 0.0110 & 0.0150 & 0.02 \\
\hline \multirow{2}{*}{$\mathrm{K}_{\text {water }}$} & Continental & 25 & 50 & 75 & 100 \\
\hline & Marine & 2 & 4 & 5 & 6 \\
\hline \multirow{2}{*}{$K_{\text {hest }}$} & Continental & 25 & 45 & 65 & 85 \\
\hline & Marine & 0.01 & 0.02 & 0.022 & 0.024 \\
\hline
\end{tabular}

$\mathrm{K}_{\text {gravity }}$ : gravity-driven diffusion coefficient; $\mathrm{K}_{\text {water }}$ : water-driven diffusion coefficient; $\mathrm{K}_{\text {hest }}$ : high-energy short-

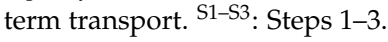

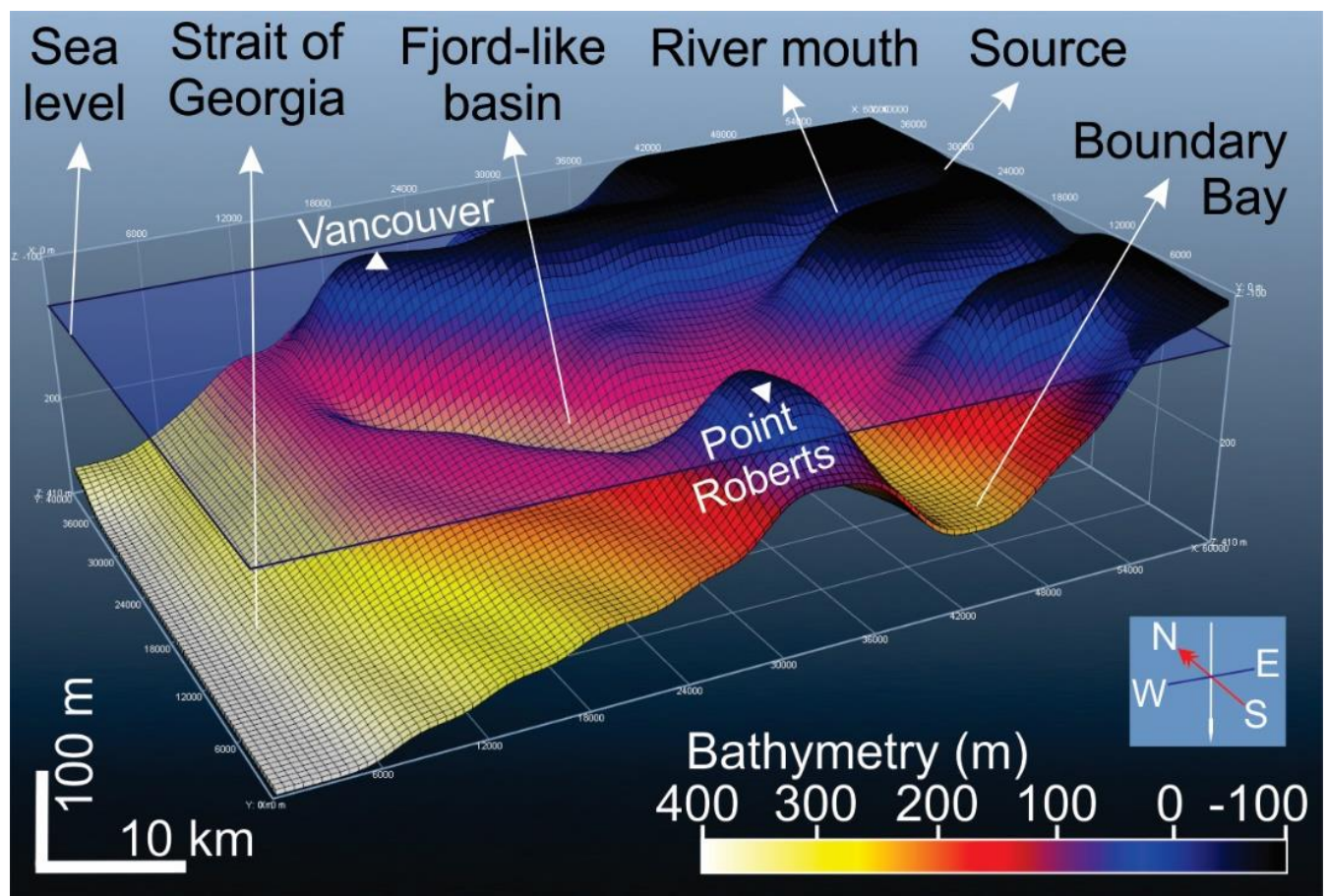

Figure 2. Initial bathymetric model characterizing the Fraser Valley before the delta progradation. The main depo-center is the "fjord-like" basin. This model was created using the thickness of modern sediments e.g., [33,34]. 


\subsubsection{Sea Level Variation}

The Fraser River Valley and its surrounding area have experienced significant sea level variations, in particular, close to the end of the last glaciation period [35,36]. At around 15,000 BP, the Fraser Valley was covered by $1.5 \mathrm{~km}$ thick glaciers [35]. Glacial retreat resulted in approximately $150 \mathrm{~m}$ relative sea level increase at around 14,000 BP. Between 14,000 and 10,000 BP, the relative sea level rapidly dropped to about $12 \mathrm{~m}$ below its present level, due to isostatic rebound [36,37]. The delta deposition started approximately 10,000 years BP (within the modelling interval herein). Sea level variation since the delta progradation initiated has received some attention, and there are various opinions. Several studies suggest that during delta progradation, relative sea level increased a noticeable $12 \mathrm{~m}$ until $2000 \mathrm{BP}$, when the relative sea level reached its current level $[3,13,38,39]$. Other studies indicate that sea level fluctuations were reported to be minor $(\sim 1 \mathrm{~m})$ [37]. Therefore, in this study, two main scenarios are considered: (1) a $12 \mathrm{~m}$ increase between 10,000 and 2000 BP, and (2) a constant (zero) sea level throughout the modern Fraser River Delta evolution (step 1-2). Some recent studies also suggest that relative sea level might increase up to $2 \mathrm{~m}$ in the next 100 years, mainly due to anthropogenic effects $[33,40]$. The potential results of this relative sea level increase are also tested in this study.

\subsubsection{Sediment Supply and Water Discharge}

Sediment supply and water discharge values are important input parameters in forward stratigraphic modelling, as they transport sediments and fill up the given accommodation space in siliciclastic settings. The majority of modelling studies use today's reported world river values $[18,41]$ to achieve realistic results in ancient settings, e.g., [28,42,43]. This approach is useful in ancient settings; however, real-time Fraser River discharge and sediment supply values are used in this study, as well as river location and width.

In the model, river discharge values vary between $4500 \mathrm{~m}^{3} / \mathrm{s}$ and $6000 \mathrm{~m}^{3} / \mathrm{s}$ (Table 1). These values are slightly higher than today's average values, mainly because the reported values represent recent real-time data and do not consider the fact that the discharge rate was most likely higher in the past due to the extensive glacial melting, particularly close to the early stages of the delta progradation. Nevertheless, these values are lower than today's maximum discharge rate.

Although annual river discharge values are known, it is also important to consider long-term variations along the river systems. In the Fraser River, extreme flooding events take place every 500 years [44]. The last extreme flood was reported in 1894 [45]. Thus, in the model, short-term high-energy floods (HEST) are applied to represent extreme floods [46].

\subsubsection{Sediment Transport Parameters}

Dionisos is based on diffusion process that is controlled by several parameters, including diffusion coefficient, water discharge, and slope [4,7,47,48]. Among these, the diffusion coefficient is perhaps the most challenging parameter to determine, as it is calculated based on variants that are difficult to quantify, such as grain shape and size, and accommodation space [48]. The diffusion coefficients used in this model are similar to other models and are listed in Table $1[4,28,48,49]$.

\section{Results}

Evolution of the Fraser River Delta is simulated using two 5000 year time spans (Figure 3). The model shows today's delta evolution in two steps (Figure 3A-L) and provides an additional third step representing the hypothetical evolution over 5000 years into the future, assuming continuous natural conditions (e.g., without anthropogenic effects) (Figure 3M-R). 

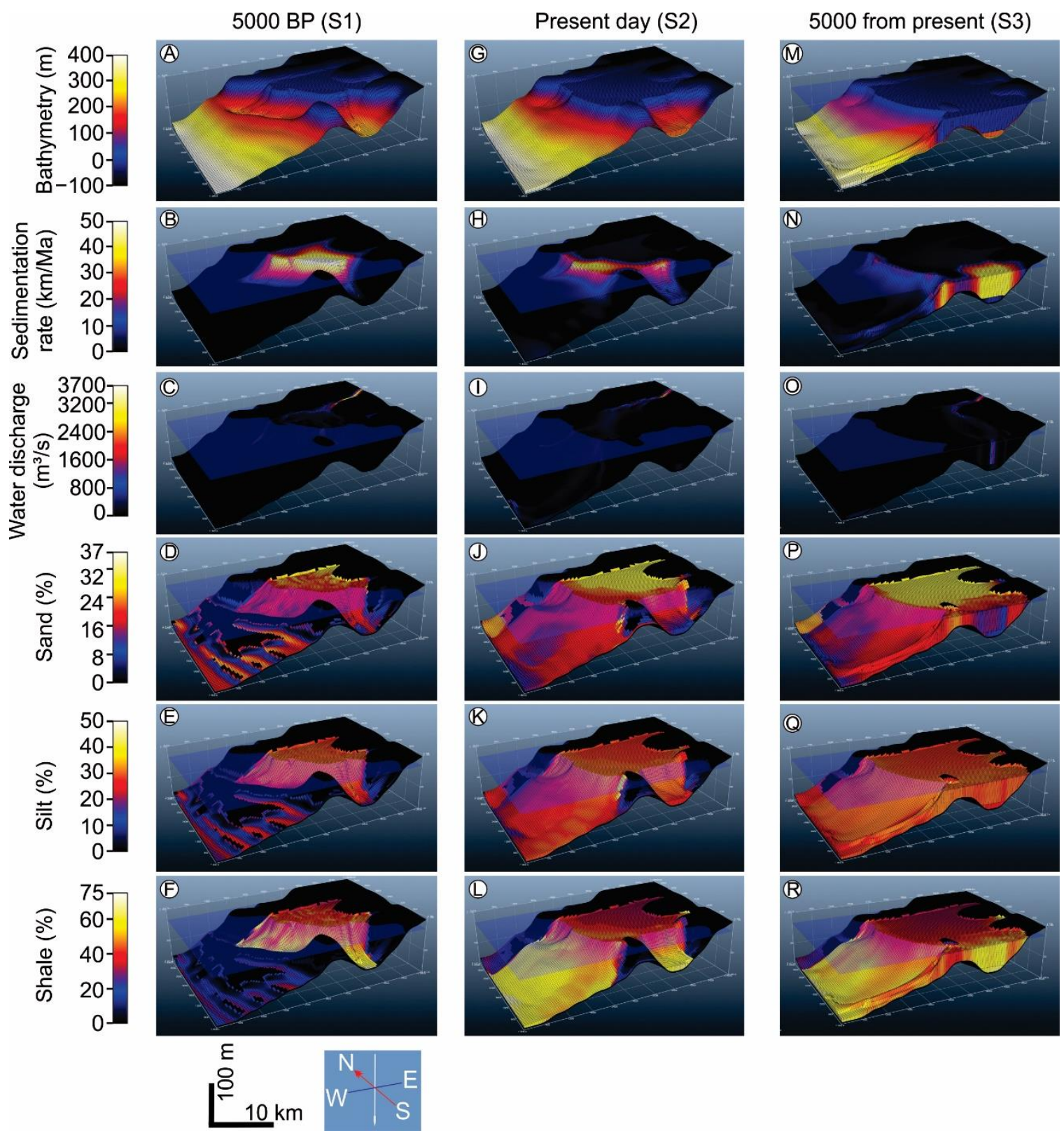

Figure 3. Simulation results demonstrating the delta characteristics and its evolution in three time steps (S1-S3). (A-F) Modelling results between 10,000 BP and 5000 BP (S1). (G-L) Modelling results between $5000 \mathrm{BP}$ and present day (S2). (M-R) Modelling results of a hypothetical test run, representing the delta's future evolution, considering no changes in the input parameters for the next 5000 years.

\subsection{Step $1(10,000 \mathrm{BP}$ to $5000 \mathrm{BP})$}

In the first step (S1), the model is created using sediment supply and water discharge values that are slightly higher than those of today's values (Table 1). Sediments fill up almost half of the fjord-like basin (Figure 3A,B). The delta plain shows approximately $15 \mathrm{~km}$ progradation in the southeast direction (Figure $3 \mathrm{~A}$ ). At the end of S1, water discharge shows two main flow paths: one flowing west and one flowing south (Figure $3 \mathrm{C}$ ). The sedimentation rate shows a significant increase in the southern delta front and delta plain, and to a lesser extent, in the northern delta front (Figure 3B).

Overall grain size distribution changes significantly from the upper delta plain to the prodelta (Figure 3D-F). The upper delta plain is dominated by sandy deposits, while the 
lower delta plain and the delta front are dominated by silty deposits (Figure 3D-F). The middle delta plain shows locally sand-rich and shale-rich patchy sediment distribution (Figure 3D), while the prodelta is mainly dominated by shale-rich units (Figure 3F). Very little sediment exceeds the fjord-like basin and deposit in the offshore (i.e., Strait of Georgia).

\subsection{Step 2 (5000 BP to Present Day)}

The second step (S2) successfully modeled today's delta morphology using sediment supply and water discharge values that are similar to present-day values (Table 1). In S2, sediments filled up the entire fjord-like basin and partially filled the Strait of Georgia (Figure 3G,H). Overall delta plain progradation reached about $24 \mathrm{~km}$ from the river mouth (Figure 3G). The model shows a major westward progradation during S2, but southward progradation is also noticeable (east of Point Roberts, Figure 3H). Water discharge, on the other hand, converged between Vancouver highland and Point Roberts, and bifurcated into two channels: a central channel (similar to today's Main Channel) and a south channel, situated close to Point Roberts (Figure 3I). Due to the complexity in sedimentation rate and grain size distribution, the west progradation is divided into two: the north delta and south delta, separated by the central channel. The south progradation (east of the Point Roberts) is also named the Boundary Bay delta (Figure 1). The overall sedimentation rate trend is at the delta front-delta plain boundary, with a slight increase at the south delta (Figure 3H).

The grain size distribution shows a uniform pattern throughout the delta plain and delta front during S2 (Figure 3J-L), particularly in silt percentage (Figure 3K). Sand and shale percentages, on the other hand, show a slight variation in the south delta (Figure 3J,L). When the grain size distribution in the delta front and delta plain is compared, the south delta front and delta plain represent slightly less sand content and more shale content (Figure 3J-L). The prodelta shows a pronounced increased in shale content (Figure 3L).

\subsection{Simulation Step 3 (5000 Years from Present)}

Step 3 (S3) represents a future scenario, presuming that all the parameters in step 2 continue operating without any modification, including sediment supply and water discharge (Table 1). Some dramatic changes are observed in the orientation of the delta progradation in S3. Delta progradation is recorded to display a shift from west to south direction (Figure $3 \mathrm{M}, \mathrm{N}$ ). Westward progradation was limited to $2-3 \mathrm{~km}$, while southern progradation (Boundary Bay) exceeded the domain limits (Figure $3 \mathrm{~N}$ ) and overflowed towards the west after filling Boundary Bay. The water flow clearly shows that the main direction of the flow also shifted towards the south (Figure 3O). Consequently, sedimentation was mainly concentrated in the Boundary Bay delta (Figure 3N).

In S3, the delta plain is overwhelmingly represented by sandy sediments (Figure 3P). The Boundary Bay delta, where major sedimentation occurs, is dominated by shale and silt deposits (Figure 3O-R). Based on the model, shale-rich sediments are trapped in the Boundary Bay delta, while sandy and silty sediments overflow into the western basin (Figure 3P-R).

\subsection{Facies Model}

Utilizing grain size distribution and water depth, a facies distribution model is created along and across the Fraser River Delta, covering all simulated steps (Figure 4 and Table 2). In the delta plain (above zero sea level), the percentage of sand distribution is selected as the main facies controlling grain size, due to the overall sandy nature of the modern delta. Shale-rich zones are defined as having less than $20 \%$ sand, while sandy zones are defined as more than $25 \%$ sand (Table 2). In the subaqueous portion, the boundary between the delta front and prodelta is selected as $150 \mathrm{~m}$, to simulate the real delta boundary [22]. Sand percentage progressively reduces from the delta plain to the prodelta; thus, $20 \%$ sand is selected to differentiate facies in the delta front, and $15 \%$ sand in the prodelta (Table 2). 

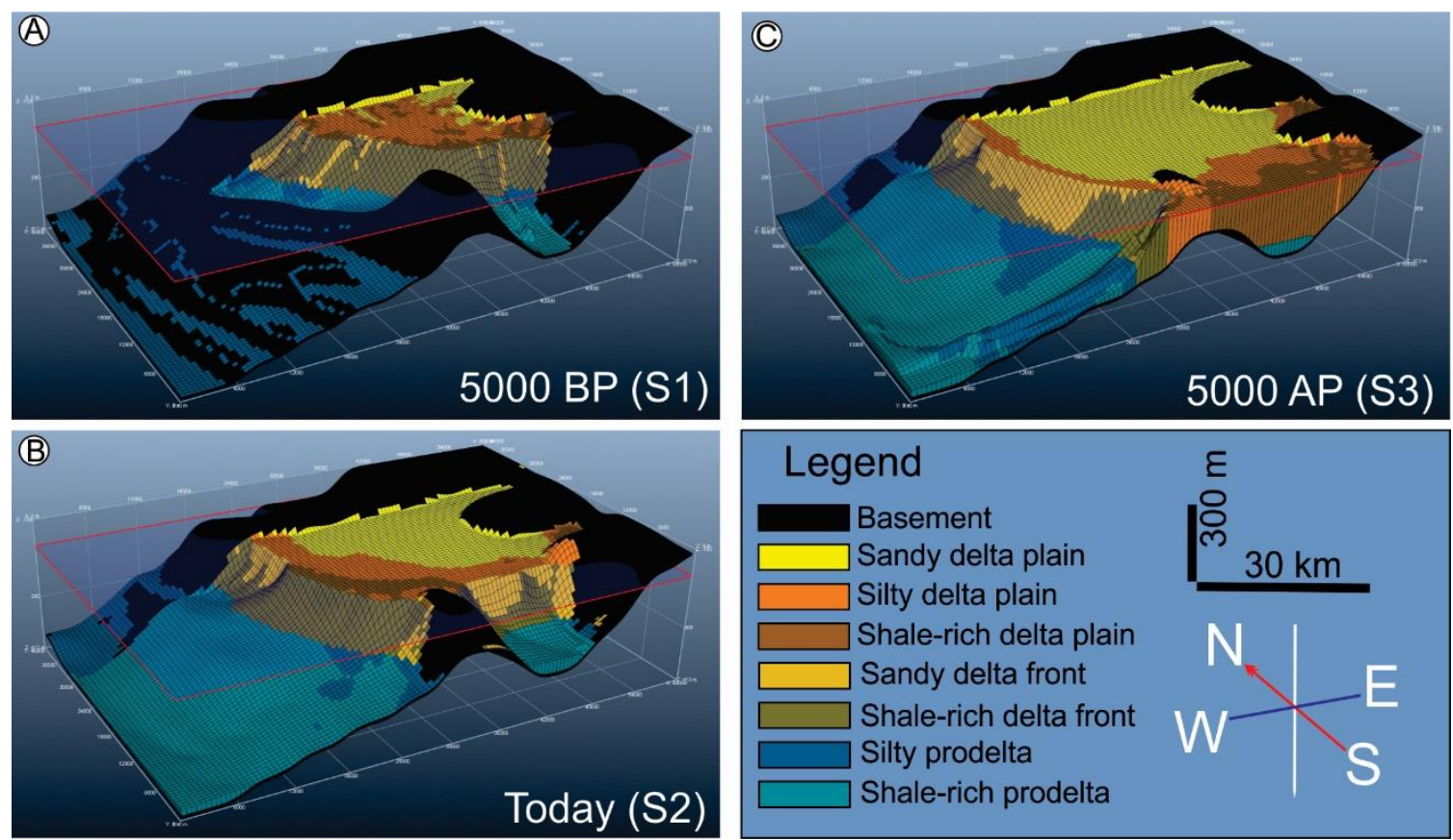

Figure 4. (A-C) Spatial facies distribution plots at the end of each time step, interpreted based on grain size percentage and bathymetric data (Table 2).

Table 2. Grain size and bathymetric parameters utilized to interpret facies distribution.

\begin{tabular}{ccccccc}
\hline \multicolumn{1}{c}{ Facies } & \multicolumn{2}{c}{ Bathymetry $(\mathbf{m})$} & \multicolumn{2}{c}{ Sand (\%) } & \multicolumn{2}{c}{ Shale (\%) } \\
\hline & Min. & Max. & Min. & Max. & Min. & Max. \\
\hline Sandy delta plain & -164 & 0 & 25 & 38.2 & - & - \\
\hline Silty delta plain & -164 & 0 & 20 & 25 & - & - \\
\hline Shale-rich delta plain & -164 & 0 & 0 & 20 & - & - \\
\hline Sandy delta front & 0 & 150 & 20 & - & - & - \\
\hline Shaley delta front & 0 & 150 & 0 & 20 & - & - \\
\hline Silty prodelta & 150 & 400 & 15 & 36.6 & 0 & 50 \\
\hline Prodelta shale & 150 & 400 & - & - & 50 & 74.7 \\
\hline
\end{tabular}

The results show that in $\mathrm{S} 1$ the upper delta plain is represented by sandy deposits, while the middle and lower delta plain is predominantly silty deposits (Figure 4A). The delta front shows almost uniform shale-rich deposits, and the prodelta is dominated by silt- and shale-rich deposits (Figure 4A). S2 shows a significant change, especially in the delta plain (Figure 4B). The upper and middle delta plain show sand-dominated deposits, while the lower delta plain shows silty deposits and, to a lesser extent, shale-rich deposits (Figure 4B). The vast majority of the delta front is characterized by shale-rich deposits, but local sand-rich deposits are present in the northern delta front (close to Vancouver) and the Boundary Bay delta (Figure 4B). The prodelta is represented by shale-rich deposits in both the Strait of Georgia and Boundary Bay delta (Figure 4B). S3 allows us to predict possible changes in facies distribution in the future. S3 shows that in 5000 years, the majority of the delta plain will be sand-rich, with local silty deposits at the edge of today's delta plain-delta front boundary and at the Boundary Bay delta (Figure 4C). Similarly, the delta front will also be dominated by sand-rich deposits. The distal portion of the delta front will be shale-rich (Figure 4C). The prodelta in S3 will remain shale-rich, but a local silt-rich deposition will develop in the south delta front (close to Point Roberts) (Figure 4C). Boundary Bay seems to be filled with shale-rich deposits; however, it is clear that these sediments would be 
dispersed southward if the outer edge of the model was bigger. Therefore, the subaqueous Boundary Bay delta deposition is ignored in S3. Unfortunately, accurate paleobathymetric data covering the south of Boundary Bay is not available to extend the model southward.

\subsection{Testing Possible Future Variations in the Fraser River Delta}

Perhaps one of the most exciting capacities of forward stratigraphic modelling applications in modern environments is to test and predict changes in future morphological and stratigraphic architecture. In this study, a future model in one step (S3) is created by presuming no changes in today's input variations (Figure 3M-S). Then, we also test how the delta can evolve if sediment supply and water discharge values change over time. In this test, sand distribution maps were plotted to represent the evolution of the delta (Figure 5). Erosion maps were also plotted and compared to visualize under which conditions the delta might become unstable (Figure 6). The results of these tests show that if the sediment supply gradually increases while the water discharge gradually decreases, the majority of the sediments will not reach offshore and will be trapped at the river mouth, creating a bulge inland (Figure 5). In this scenario, only a slight erosion is observed in the distal parts of the prodelta (Figure 6). In contrast, when sediment supply gradually decreases while water discharge increases, delta progradation slows significantly, and local or regional erosion takes place (Figure 6). Erosion first starts in the upper delta plain and gradually affects the entire delta as the discharge rate increase and sediment supply decrease (Figure 6). Erosion results in exposure of underlying sand-rich delta plain and delta front deposits (Figure 5). When both sediment supply and water discharge increase, the delta shows progradation in all directions offshore, with little or no erosion (Figures 5 and 6). In this scenario, erosion occurs when discharge is more than $6750 \mathrm{~m}^{3} / \mathrm{s}$ and sediment supply is less than $13,500 \mathrm{~km}^{3} / \mathrm{Ma}$ (Figure 6). These results can play a critical role when further modifications on the river (such as placing a dam) are considered.

In addition to variations in sediment supply and water discharge, a possible sea level variation is also tested in this study. The effect of sea level variations in coastal areas is a global issue due to several reasons, such as global warming and anthropogenic influence. The Fraser River Delta may also face this issue, due to the fact that parts of the delta plain show noticeable subsidence, possibly resulting in a $2 \mathrm{~m}$ increase in the next 100 years [33,40]. In Dionisos software, testing variations over 100 years is not possible; however, if one considers that this relative sea level increase will remain constant in the next modelling time step, it is possible to test how stratigraphic architecture can respond to such variation. Therefore, a $100 \mathrm{~m}$ relative sea level increase is tested, maintaining all other parameters similar to step 2 (Figure 7). The results show a dramatic shift in the evolution of the delta: from an overall prograding system to a retrograding system (Figure 7). Sediments during this scenario deposit mostly on the Boundary Bay area, but a clear backstepping deposition is also visible on the delta plain (Figure 7). The majority of the sand accumulates on the upper delta plain (Figure 7A), while silty deposits show uniform distribution throughout the delta (Figure 7B) and shale unit deposits predominate the prodelta (Figure 7C). Water discharge shows a southward deflection towards Boundary Bay (Figure 7D), similar to step 3. No negative effect in terms of delta stability (e.g., major erosion) is observed, but it cannot be ruled out that if this scenario takes place wave erosion can be a major concern on the delta plain, resulting in a wave ravinement-like surface. 


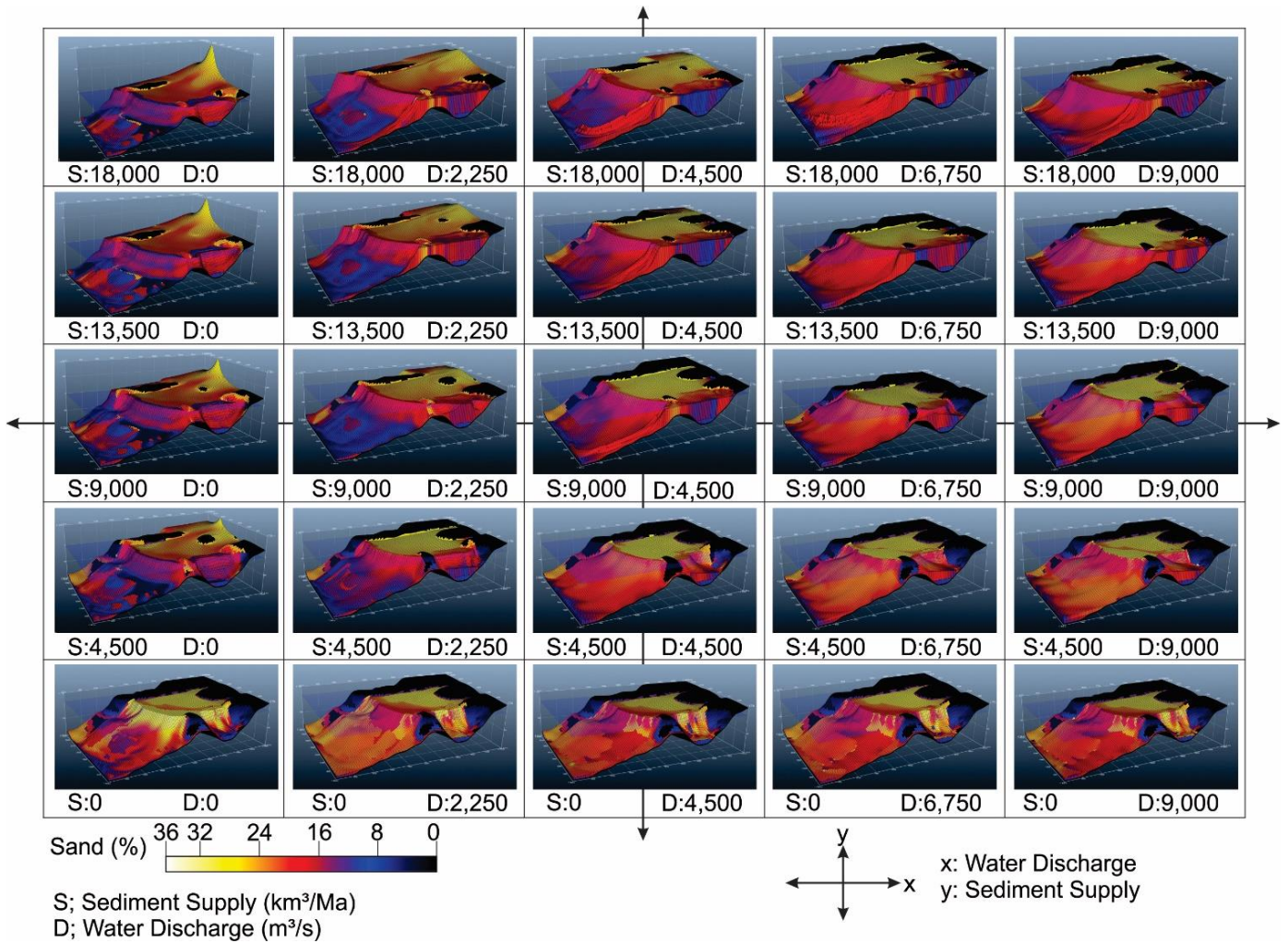

Figure 5. Hypothetical delta evolution in the next 5000 years with variant sediment supply and water discharge values. Please note that the block diagram in the center (S3) represents no changes in sediment supply and water discharge values (similar parameters used in S2).

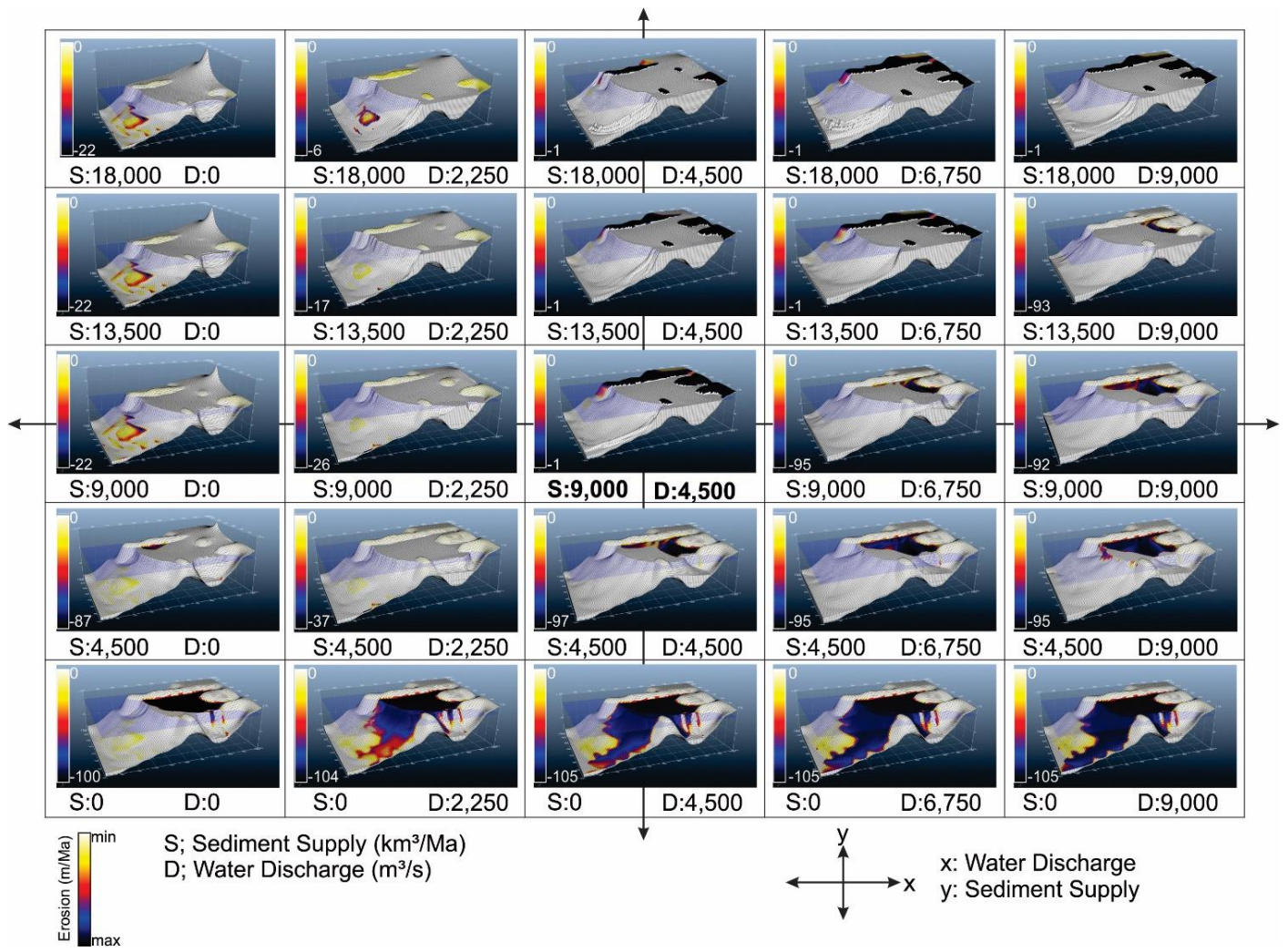

Figure 6. Results showing erosion rate (m/MA) maps in the next 5000 years with variant sediment supply and water discharge values. 

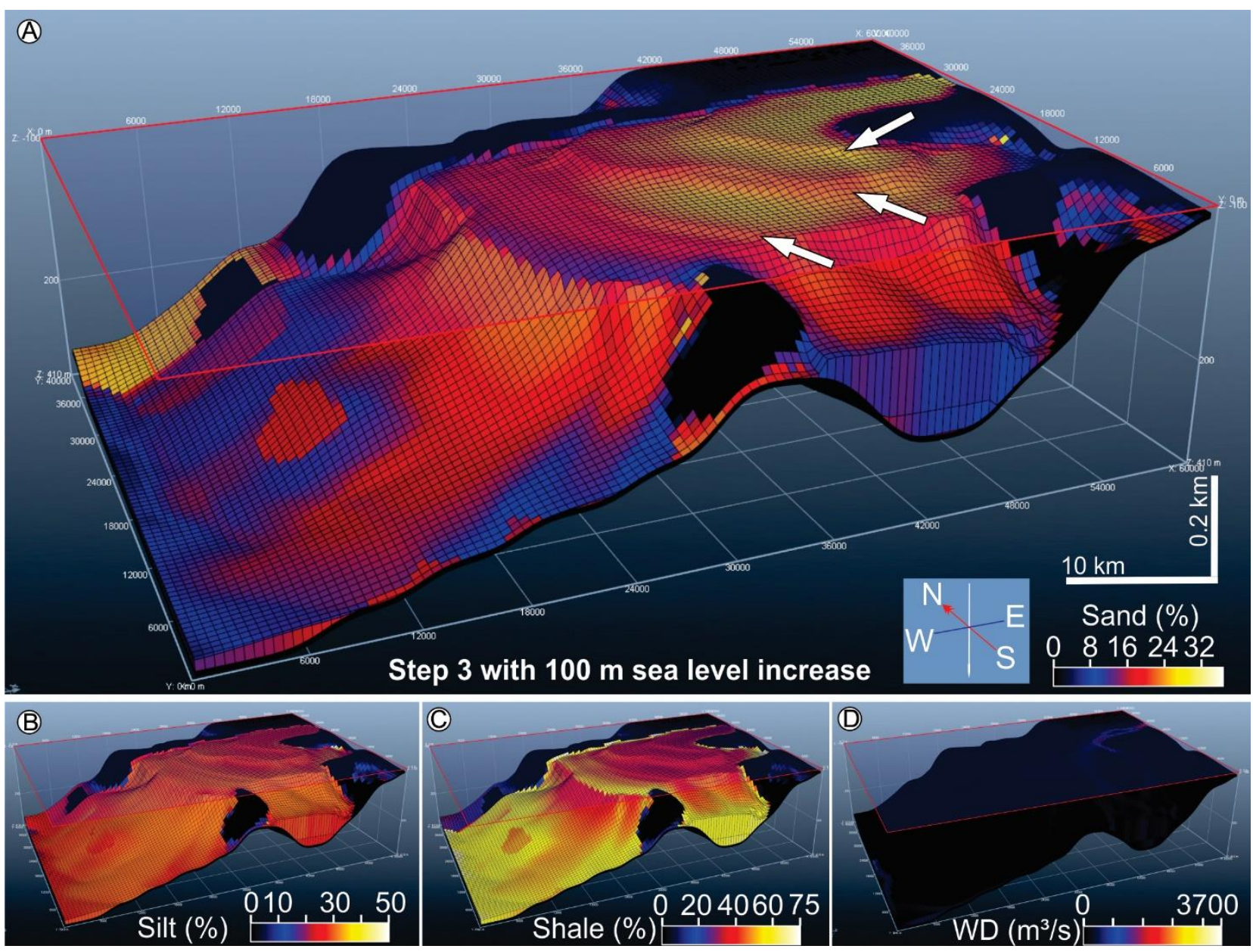

Figure 7. (A-D) Modelling results representing the effects of a hypothetical $100 \mathrm{~m}$ relative sea level increase in the next 5000 years. It should be noted that in this model, only the sea level curve was introduced to the model; other parameters remain similar to step 2 (Figure 3G-L and Table 1).

\section{Discussion}

The simulated Fraser River Delta, particularly its evolution and progradation rate, is similar to what has been documented in the literature, e.g., [10,50] suggesting that the majority of the input parameters used in this study were predicted accurately. Diffusion coefficients adopted from other studies were documented to work correctly, because other input parameters used in this study are real-time or close to real values. Although each parameter played a critical role in the model, sediment supply and water discharge values were the main controlling mechanisms. Today's known values and available data (e.g., paleobathymetry, river discharge, and sediment supply) were enough to successfully simulate the overall stratigraphic architecture, shoreline morphology, and delta progradation, particularly in S2 (Figure 3G-L). However, some parameters were modified in S1, considering changes in paleodepositional conditions.

Today's sediment supply and water discharge values were observed to be too low to replicate the progradation of the delta in the first 5000 years to fill up the accommodation space (Table 1 and Figure 3A,B). Following several attempts, it was realized that the river discharge and sediment supply values during S1 must have been slightly higher than today's values (Table 1). Given that the Fraser River Delta is a post-glacial setting, the higher values suggest rapid melting of glaciers, increasing both sediment supply and water discharge. Similar variations have been documented in other deltas located in high latitude areas, e.g., [51]. Today, the Fraser Delta experiences similar yearly low and high sediment supply and water discharge values in winter and summer, respectively. During the summer 
season, both values are significantly higher due to melting of accumulated snow, while they are lower when snow accumulates in highland areas [32,52].

The two sea-level variation scenarios displayed dramatic differences in delta progradation. A constant sea level (zero fluctuation) successfully created the delta progradation up to its today's limits. However, a $12 \mathrm{~m}$ sea level increase failed to generate a realistic model. When a $12 \mathrm{~m}$ sea level increase was used, sediments were trapped in the delta plain region, and delta progradation stopped short of today's delta limits, despite countless attempts to change and test variations in parameters (e.g., sediment supply and diffusion coefficients). Although this observation may suggest that the Fraser Delta has not experienced major sea level fluctuations, it should be noted that there are other parameters that may have contributed to delta progradation. For example, the net northward sediment transportation due to strong tidal currents [21,25] or deep-water renewal events, bringing external sediments into the Fraser basin [23], may have played a role in supplying additional sediments to the delta. If these processes were sufficient, the delta progradation could reach to its current limits under a $12 \mathrm{~m}$ sea level increase. Unfortunately, testing these processes is beyond the current capacity of the software.

Perhaps one of the most important parameters to validate the delta evolution between a real system and a modelled system is the progradation rate. The Fraser River Delta's progradation rate has previously been documented, based on the sedimentological record $[11,13,15,50]$. The model successfully created a similar progradation rate in two steps (Figure 3). The simulated first and second steps displayed $15 \mathrm{~km}$ and $9 \mathrm{~km}$ (cumulative: $\sim 24 \mathrm{~km}$ ) progradation, respectively (Figure 3).

Water discharge data show pathways for major channels. In the Fraser River Delta, the location of the main distributary channel is unknown at $5000 \mathrm{BP}$, but it has been suggested that the river system was at one point flowing east of Point Roberts (towards the Boundary Bay delta) before shifting toward the Strait of Georgia, as in today [10,17]. The model displays one major and one subordinate river system at the end of S1 (Figure 3C). The major system flows towards the west (similar to present day), while the subordinate one flows south, into the Boundary Bay delta. The major system shows the highest water discharge values, suggesting that this might be the main distributary channel at $5000 \mathrm{BP}$, but the smaller system also suggests that the main channel might have shifted frequently. Increased sedimentation rate at the Boundary Bay delta during S1 (Figure 3B) shows that majority of the sediments were deposited in Boundary Bay. This may suggest that distributary channels predominantly flowed towards Boundary Bay at early stages of the delta progradation, which is concordant with previous estimations, e.g., [10,17]. In the present day, the Fraser River has one main distributary channel (Main Channel; Figure 1) and a few subordinate channels. Recent channel locations and migration pathways have been well documented [53]. The main channel of the Fraser River shows frequent shifts between the south of today's main channel and the north of Point Roberts (south delta plain) in the early to late 1800s, until it was controlled by placing dykes in 1912 [15]. These frequent shifts in the main channel have been linked to downstream migrating bars obstructing channels and resulting in water flowing into other channels [54]. Although such small-scale bar formations are beyond the resolution of Dionisos software, the model successfully simulated overall channel systems (Figure 3I). This suggests that the main water flow pathways can also be closely predicted using forward stratigraphic modelling at the end of each time step.

The test results for step 3 show a dramatic shift in the main channel direction from the westward flowing to southward (into Boundary Bay) flowing pathway (Figure 3O). This indicates that under natural conditions, the river could be shifted towards the Boundary Bay delta within the next 5000 years. Although the model does not show a major erosion in today's delta plain and delta front, it should be noted that tides and waves are reported to cause local erosion in the south of today's delta front, and they still have the potential to create major stability issues [21]. 
Comparison of grain size variation and facies changes in the Fraser River Delta is complicated due to the dynamic nature of the river, resulting in frequent variations in depositional environments throughout the delta, e.g., $[30,55,56]$. The model also shows that grain size and facies distribution vary significantly in space and time (Figures 3 and 4). Although overall facies and grain size architectures show similarities with published studies, and the delta shows a clear coarsening upward succession, finer resolution facies maps to correlate or calibrate it with the real-time data could not be achieved due to the limitations in the resolution of the modelling software. Moreover, hydrodynamic conditions in the SoG are controlled by tides and deep-water currents $[17,23,57]$, which are beyond the capacity of the Dionisos.

\section{Conclusions}

Forward stratigraphic modelling is applied to the modern Fraser River Delta, Canada, using Dionisos software. The results document that modern siliciclastic systems can be simulated using real-time input parameters and can help predict future geomorphological changes and stratigraphic architectures. In this study, the Fraser River Delta is successfully created in two time steps and in one further step for its future architecture. The delta evolution and how it can change with variations in sediment supply and water discharge values are documented. The possible effects of a hypothetical $100 \mathrm{~m}$ relative sea level increase in the delta evolution are also illustrated. The results document that forward stratigraphic modelling is applicable for relatively short (5000 years) time steps; therefore, it can be used in modern systems (e.g., developed following the last glaciation).

Funding: This research received no external funding.

Institutional Review Board Statement: Not applicable.

Informed Consent Statement: Not applicable.

Data Availability Statement: Not applicable.

Acknowledgments: I kindly thank Shahin E. Dashtgard and Levi J. Knapp for their helpful review of an earlier version of this manuscript. The study was supported by start-up grants from the College of Petroleum and Geosciences, KFUPM.

Conflicts of Interest: The authors declare no conflict of interest.

\section{References}

1. Huang, X.; Griffiths, C.M.; Liu, J. Recent development in stratigraphic forward modelling and its application in petroleum exploration. Aust. J. Earth Sci. 2015, 62, 903-919. [CrossRef]

2. Hawie, N.; Deschamps, R.; Granjeon, D.; Nader, F.H.; Gorini, C.; Müller, C.; Montadert, L.; Baudin, F. Multi-scale constraints of sediment source to sink systems in frontier basins: A forward stratigraphic modelling case study of the levant region. Basin Res. 2017, 29, 418-445. [CrossRef]

3. Hawie, N.; Covault, J.A.; Sylvester, Z. Grain-size and discharge controls on submarine-fan depositional patterns from forward stratigraphic models. Front. Earth Sci. 2019, 7, 334. [CrossRef]

4. $\quad$ Burgess, P.M.; Lammers, H.; van Oosterhout, C.; Granjeon, D. Multivariate sequence stratigraphy: Tackling complexity and uncertainty with stratigraphic forward modeling, multiple scenarios, and conditional frequency maps. AAPG Bull. 2006, 90, 1883-1901. [CrossRef]

5. Ayranci, K.; Dong, T.; Harris, N. Application of Forward Stratigraphic Modelling in Deep-Water Shale Basins: Insights from the Devonian Horn River Basin, BC, Canada. In Proceedings of the American Association of Petroleum Geologists ACE Annual Convention, Houston, TX, USA, 2-5 April 2017; AAPG: Houston, TX, USA, 2017.

6. Csato, I.; Catuneanu, O.; Granjeon, D. Millennial-scale sequence stratigraphy: Numerical simulation with dionisos. J. Sediment. Res. 2014, 84, 394-406. [CrossRef]

7. Granjeon, D. 3d forward modelling of the impact of sediment transport and base level cycles on continental margins and incised valleys. In From Depositional Systems to Sedimentary Successions on the Norwegian Continental Margin; Martinius, A.W., Ravnås, R., Howell, J.A., Steel, R.J., Wonham, J.P., Eds.; John Wiley \& Sons: New York, NY, USA, 2014; pp. 453-472.

8. Yin, X.; Huang, W.; Wang, P.; Wang, J.; Wang, Q.; Yan, D.; Zhou, X. Sedimentary evolution of overlapped sand bodies in terrestrial faulted lacustrine basin: Insights from 3d stratigraphic forward modeling. Mar. Pet. Geol. 2015, 86, 1431-1443. [CrossRef] 
9. Huang, X.; Liu, K.; Zou, C.; Yuan, X.; Gui, L. Forward stratigraphic modelling of the shallow-water delta system in the poyang lake, southern china. J. Geochem. Explor. 2014, 144, 74-83. [CrossRef]

10. Clague, J.J.; Luternauer, J.L.; Monahan, P.A.; Edwardson, K.A.; Dallimore, S.R.; Hunter, J.A. Quaternary stratigraphy and evolution of the fraser delta. In Geology and Natural Hazards of the Fraser River Delta, British Columbia; ClagueJ, J.J., Luternauer, L., Mosher, D.C., Eds.; Geological Survey of Canada: Ottawa, ON, Canada, 1998; pp. 57-90.

11. Clague, J.J.; Luternauer, J.L.; Pullan, S.E.; Hunter, J.A. Postglacial deltaic sediments, southern fraser river delta, British Columbia. Can. J. Earth Sci. 1991, 28, 1386-1393. [CrossRef]

12. Hart, B.S.; Barrie, J.V. Environmental geology of the fraser delta, vancouver. Geosci. Can. 1995, 22, $172-183$.

13. Williams, H.F.L. Sea-level change and delta growth: Fraser delta, British Columbia. In Department of Geography; Simon Fraser University: Vancouver, BC, Canada, 1988; p. 277.

14. Williams, H.F.L.; Roberts, M.C. Holocene sea-level change and delta growth: Fraser river delta, British Columbia. Can. J. Earth Sci. 1989, 26, 1657-1666. [CrossRef]

15. Clague, J.J.; Luternauer, J.L.; Hebda, R.J. Sedimentary environments and postglacial history of the fraser delta and lower fraser valley, British Columbia. Can. J. Earth Sci. 1983, 20, 1314-1326. [CrossRef]

16. Kostaschuk, R.A.; Luternauer, J.L.; Church, M.A. Sedimentary processes in the estuary. In Geology and Natural Hazards of the Fraser River Delta, British Columbia; Clague, J.J., Luternauer, L., Mosher, D.C., Eds.; Geological Survey of Canada: Ottawa, ON, Canada, 1998; pp. 41-56.

17. Thomson, R.E. Oceanography of the British Columbia Coast; Department of Fisheries and Oceans Canada: Ottawa, ON, Canada, 1981.

18. Milliman, J.D. Sedimentation in the fraser river and its estuary, southwestern British Columbia (Canada). Estuar. Coast. Mar. Sci. 1980, 10, 609-633. [CrossRef]

19. McLean, D.G.; Tassone, B.L. A sediment budget of the lower fraser river. In Proceedings of the 5th Federal Interagency Sedimentation Conference, Las Vegas, NV, USA, 18-21 March 1991; pp. 33-40.

20. Pharo, C.H.; Barnes, W.C. Distribution of surficial sediments of the central and southern strait of georgia, British Columbia. Can. J. Earth Sci. 1976, 13, 684-696. [CrossRef]

21. Hill, P.R.; Conway, K.; Lintern, D.G.; Meulé, S.; Picard, K.; Barrie, J.V. Sedimentary processes and sediment dispersal in the southern strait of georgia, BC, Canada. Mar. Environ. Res. 2008, 66, S39-S48. [CrossRef] [PubMed]

22. Ayranci, K.; Dashtgard, S.E. Asymmetrical deltas below wave base: Insights from the fraser river delta, canada. Sedimentology 2016, 63, 761-779. [CrossRef]

23. Ayranci, K.; Dashtgard, S.E. Deep-water renewal events; insights into deep water sediment transport mechanisms. Sci. Rep. 2020 10, 6139. [CrossRef]

24. Ayranci, K.; Dashtgard, S.E. Deep-water asymmetric deltas: A case study of the Fraser River Delta, BC, Canada. In Gussow 2016: Clastic Sedimentology: New Ideas and Applications; CSPG: Banff, AB, Canada, 2016.

25. Luternauer, J.L. Genesis of morphological features on the western delta front of the fraser river, British Columbia-status of knowledge. In Coastlines of Canada; McCann, S.B., Ed.; Geological Survey of Canada: Ottawa, ON, Canada, 1980 ; pp. $381-396$.

26. Hart, B.S. Large-scale in situ rotational failure on a low-angle delta slope: The foreslope hills, fraser delta, British Columbia, Canada. Geo-Mar. Lett. 1993, 13, 219-226. [CrossRef]

27. Euzen, T.; Joseph, P.; Du Fornel, E.; Lesur, S.; Granjeon, D.; Guillocheau, F. Three-dimensional stratigraphic modelling of the grès d'annot system, eocene-oligocene, se france. Geol. Soc. Lond. Spec. Publ. 2004, 221, 161-180. [CrossRef]

28. Crombez, V.; Rohais, S.; Baudin, F.; Chauveau, B.; Euzen, T.; Granjeon, D. Controlling factors on source rock development: Implications from 3d stratigraphic modeling of triassic deposits in the western canada sedimentary basin. Bull. Soc. Géol. Fr. 2017, 188, 30. [CrossRef]

29. Zhang, J.; Burgess, P.M.; Granjeon, D.; Steel, R. Can sediment supply variations create sequences? Insights from stratigraphic forward modelling. Basin Res. 2019, 31, 274-289. [CrossRef]

30. Luternauer, J.L.; Mosher, D.C.; Clague, J.J.; Atkins, R.J. Sedimentary environments of the fraser delta. In Geology and Natural Hazards of the Fraser River Delta, British Columbia; Clague, J.J., Luternauer, L., Mosher, D.C., Eds.; Geological Survey of Canada: Ottawa, ON, Canada, 1998; pp. 27-39.

31. Evoy, R.W.; Moslow, T.F.; Luternauer, J.L. Grain size distribution patterns supporting sediment bypassing on the fraser river delta foreslope, British Columbia. J. Coast. Res. 1997, 13, 842-853.

32. Kostaschuk, R.A.; Church, M.A.; Luternauer, J.L. Sediment transport over salt-wedge intrusions: Fraser river estuary, Canada. Sedimentology 1992, 39, 305-317. [CrossRef]

33. Mazzotti, S.; Lambert, A.; Van der Kooij, M.; Mainville, A. Impact of anthropogenic subsidence on relative sea-level rise in the fraser river delta. Geology 2009, 37, 771-774. [CrossRef]

34. Ventura, C.; Thibert, K.; Asc, M. Site period estimations using microtremor measurements-experimental and analytical studies in British Columbia. In Conference Proceedings of the Society for Experimental Mechanics Series, St Louis, MI, USA, 4-7 June 2006; Society for Experimental Mechanics (SEM): NBethel, CT, USA, 2006.

35. Clague, J.J.; Mathewes, R.W.; Guilbault, J.P.; Hutchinson, I.; Ricketts, B.D. Pre-younger dryas resurgence of the southwestern margin of the cordilleran ice sheet, British Columbia, Canada. Boreas 1997, 26, 261-278. [CrossRef]

36. Clague, J.; James, T. History and isostatic effects of the last ice sheet in southern British Columbia. Quat. Sci. Rev. 2002, 21, 71-87. [CrossRef] 
37. Fedje, D.; McLaren, D.; James, T.S.; Mackie, Q.; Smith, N.F.; Southon, J.R.; Mackie, A.P. A revised sea level history for the northern Strait of Georgia, British Columbia, Canada. Quat. Sci. Rev. 2018, 192, 300-316. [CrossRef]

38. James, T.; Hutchinson, I.; Barrie, J.V.; Conway, K.; Mathews, D. Relative sea-level change in the northern strait of georgia, British Columbia. Géogr. Phys. Et Quat. 2005, 59, 113-127. [CrossRef]

39. Clague, J.; Harper, J.R.; Hebda, R.J.; Howes, D.E. Late quaternary sea levels and crustal movements, coastal British Columbia. Can. J. Earth Sci. 1982, 19, 597-618. [CrossRef]

40. Samsonov, S.V.; d'Oreye, N.; González, P.J.; Tiampo, K.F.; Ertolahti, L.; Clague, J.J. Rapidly accelerating subsidence in the greater vancouver region from two decades of ers-envisat-radarsat-2 dinsar measurements. Remote Sens. Environ. 2014, 143, $180-191$. [CrossRef]

41. Milliman, J.D.; Syvitski, J.P.M. Geomorphic/tectonic control of sediment discharge to the ocean: The importance of small mountainous rivers. J. Geol. 1992, 100, 525-544. [CrossRef]

42. Hawie, N.; Barrois, A.; Marfisi, E.; Murat, B.; Hall, J.; El-Wazir, Z.; Al-Madani, N.; Aillud, G. Forward Stratigraphic Modelling, Deterministic Approach to Improve Carbonate Heterogeneity Prediction; Lower Cretaceous, Abu Dhabi; Society of Petroleum Engineers: Dallas, TX, USA, 2015; p. 15.

43. Harris, A.D.; Covault, J.A.; Madof, A.S.; Sun, T.; Sylvester, Z.; Granjeon, D. Three-dimensional numerical modeling of eustatic control on continental-margin sand distribution. J. Sediment. Res. 2016, 86, 1434-1443. [CrossRef]

44. Council, F.B. Lower Mainland Flood Strategy (Phase 1 Summary Report); Fraser River Council: Victoria, BC, Canada, 2016.

45. Basiru, M.A. In Search of Cordilleran Point Sources to the Southern Mcmurray Sub-Basin; Simon Fraser University: Burnaby, BC, Canada, 2016.

46. Granjeon, D. Use of high-performance stratigraphic forward modelling to improve siliciclastic and carbonate reservoir depositional architecture description. J. Jpn. Assoc. Pet. Technol. 2018, 84, 59-70. [CrossRef]

47. Granjeon, D.; Joseph, P. Concepts and applications of a 3-d multiple lithology, diffusive model in stratigraphic modeling. Numerical Experiments in Stratigraphy: Recent Advances in Stratigraphic and Sedimentologic Computer Simulations. SEPM Soc. Sediment. Geol. 1999, 62, 197-210.

48. Gvirtzman, Z.; Csato, I.; Granjeon, D. Constraining sediment transport to deep marine basins through submarine channels: The levant margin in the late cenozoic. Mar. Geol. 2014, 347, 12-26. [CrossRef]

49. Bruneau, B.; Chauveau, B.; Baudin, F.; Moretti, I. 3d stratigraphic forward numerical modelling approach for prediction of organic-rich deposits and their heterogeneities. Mar. Pet. Geol. 2017, 82, 1-20. [CrossRef]

50. Roberts, M.C.; Murty, T.S. Influence of delta growth on paleo-tidal flow: Fraser river delta, British Columbia. Part 1: Geological framework and evolution of the delta. Mar. Geod. 1989, 13, 221-228. [CrossRef]

51. Wada, T.; Chikita, K.A.; Kim, Y.; Kudo, I. Glacial effects on discharge and sediment load in the subarctic tanana river basin, alaska. Arct. Antarct. Alp. Res. 2011, 43, 632-648. [CrossRef]

52. Kostaschuk, R.A.; Luternauer, J.L.; Barrie, J.V.; Leblond, P.H.; Von Deichmann, L.W. Sediment transport by tidal currents and implications for slope stability: Fraser river delta, British Columbia. Can. J. Earth Sci. 1995, 32, 852-859. [CrossRef]

53. Murray, A. Fraser River Delta: Southern British Columbia (Canada). In The Wetland Book; Finlayson, C.M., Milton, G.R., Prentice, R.C., Davidson, N.C., Eds.; Springer: Dordrecht, The Netherlands, 2018; pp. 565-575.

54. Johnson, W.A. Sedimentation of the Fraser River Delta; Geological Survey of Canada: Ottawa, ON, Canada, $1921 ;$ p. 46.

55. Dashtgard, S.; Venditti, J.; Hill, P.; Sisulak, C.; Johnson, S.; La Croix, A. Sedimentation across the tidal-fluvial transition in the lower fraser river, canada. Sediment. Rec. 2012, 10, 4-9. [CrossRef]

56. Clague, J.J. Geological setting of the fraser delta. In Geology and Natural Hazards of the Fraser River Delta, British Columbia; Clague, J.J., Luternauer, L., Mosher, D.C., Eds.; Geological Survey of Canada: Ottawa, ON, Canada, 1998; pp. 7-16.

57. Mosher, D.C.; Thomson, R.E. The foreslope hills; large-scale, fine-grained sediment waves in the strait of georgia, British Columbia. Mar. Geol. 2002, 192, 275-295. [CrossRef] 